\title{
PENGARUH PERSEPSI SISWA TENTANG SUASANA KEHIDUPAN SEKOLAH TERHADAP MOTIF BERPRESTASI
}

\author{
Sisti Nurlina, Adang Hambali \& Fridayanti \\ Fakultas Psikologi UIN Sunan Gunung Djati Bandung, Jl. A.H Nasution No. 105 Bandung \\ email: shesty.tie@facebook.com
}

\begin{abstract}
Abstrak
Penelitian ini berawal dari fenomena mengenai adanya siswa yang memiliki presepsi positif serta persepsi yang negatif terhadap suasana kehidupan sekolah. Dua sisi persepsi siswa tersebut diduga mempengaruhi motif berprestasinya karena secara tidak langsung mempengaruhi kesesuaian antara apa yang diusahakan siswa dalam melaksanakan proses belajar di sekolah dengan kebutuhan yang ingin di penuhi. Pendekatan yang digunakan dalam penelitian ini adalah pendekatan kuantitatif, sedangkan metoda yang digunakan adalah korelasional sebab akibat. Populasi dalam penelitian ini adalah semua siswa kelas IX SMP Mika Bakti yang berjumlah 34 orang. Untuk mengetahui adanya pengaruh dalam penelitian ini, peneliti menggunakan statistik uji analisis regresi sederhana. Berdasarkan hasil uji statsitik diketahui bahwa nilai $F$ hitung sebesar 0.139 dengan tingkat signifikansi 0.712 (tidak signifikan) dengan nilai probabilitas 0,712 lebih besar dari 0,05. Dengan demikian dapat disimpulkan bahwa persepsi siswa tentang suasana kehidupan sekolah tidak berpengaruh secara signifikan terhadap motif berprestasi pada siswa kelas IX SMP Mika Bakti Ciparay.
\end{abstract}

Kata kunci: persepsi, suasana kehidupan sekolah dan motif berprestasi

\section{Abstract}

This research based on phenomena about students whose positive and negative perception about school life. Those two perceptions are expected effecting achievement motive and effort in learning process. This quantitative research used caused and effect correlation. Population are 34 students from grade IX SMP Mika Bakti. Simple regression analysis is used to study the effect in this research. Statistical analysis result shows $F$ value is 0.139 with significant level 0.712 (not significant) and probability value is 0,712 more than 0,05. It is concluded that student perception about school life does not significantly effect achievement motive on students at SMP IX Mika Bakti Ciparay.

Keywords : perception, school life situation, and achievemnet motive

\section{PENDAHULUAN}

Arus globalisasi yang ditandai dengan liberalisme perdagangan antar bangsa menjadi tantangan mutlak yang harus direspon oleh semua komponen bangsa, terutama institusi pendidikan yang mempunyai peran dan fungsi strategis dalam mempersiapkan dan membentuk sumber daya manusia (SDM) yang unggul dan professional. Upaya pengembangan SDM melalui institusi pendidikan tertuang dalam tu- juan pendidikan nasional yang tercantum dalam undang-undang sistem pendidikan nasional (Sisdiknas) No.02 Tahun 2003, yaitu sebagai berikut: "Pendidikan nasional bertujuan untuk berkembangnya potensi peserta didik agar menjadi manusia yang beriman dan bertakwa kepada Tuhan yang maha esa, berakhlak mulia, sehat, berilmu, cakap, kreatif, mandiri dan menjadi warga negara yang demokratis serta bertanggungjawab". 
Dengan peningkatan kualitas SDM serta ditunjang iklim belajar mengajar yang dapat menumbuhkan rasa percaya diri, inovatif, dan kreatif, maka akan mampu mewujudkan manusia-manusia pembangun yang dapat membangun diri sendiri serta bersama-sama bertanggung jawab atas pembangunan bangsa. Untuk mewujudkan harapan tersebut, peran generasi muda sebagai penerus cita-cita bangsa tentulah harus mempunyai tanggung jawab yang besar, cerdas, bermental baja, cekatan dan tangguh dalam menghadapi segala macam tantangan kemajuan zaman.

Pendidikan mempunyai peranan penting yang sangat menentukan, tidak hanya bagi perwujudan dan perkembangan diri individu tetapi juga bagi pembangunan bangsa dan negara. Kemajuan suatu bangsa tergantung bagaimana bangsa tersebut mengenali, menghargai dan memanfaatkan sumber daya manusia. Hal ini berkaitan dengan kualitas pendidikan yang diberikan kepada anggota masyarakatnya.

Sekolah merupakan lembaga pendidikan formal yang secara sistematik melaksanakan program bimbingan, pengajaran, dan latihan dalam rangka membantu siswa agar mampu mengembangkan potensinya, baik yang menyangkut aspek moral-spiritual, intelektual, emosional maupun sosial (Yusuf, 2000: 95).

Menurut Dewey (dalam Nurlaela, 2004) sekolah mempunyai dua fungsi utama, yaitu fungsi psikologis dan sosial. Fungsi psikologis yaitu membimbing perkembangan psikologis anak dan fungsi sosialnya yaitu untuk membantu mempersiapkan peserta didik sebagai anggota masyarakat bagi kehidupan masyarakat mendatang. Dengan demikian sekolah mempunyai peluang besar dalam mempengaruhi perkembangan anak.

Gambaran keberhasilan pendidikan setiap saat selalu menjadi sorotan. Berbagai pandangan dikemukakan baik yang bersifat kritik maupun penilaian lainnya terhadap apa yang menjadi hasil suatu proses pendidikan. Prestasi belajar siswa merupakan salah satu aspek hasil proses pendidikan yang mudah menjadi sorotan dan paling sering dibicarakan dalam dunia pendidikan. Dalam dunia pendidikan, prestasi merupakan suatu hasil belajar yang dicapai siswa sehingga untuk mencapai prestasi tersebut, para siswa terlebih dahulu dituntut untuk mengikuti proses belajar mengajar di sekolah, dan mengikuti aturan-aturan sekolah sesuai dengan ketentuan akademik.
Terdapat beberapa faktor yang turut menentukan pencapaian prestasi belajar siswa, baik yang berkaitan dengan faktor individu atau kepribadian seseorang maupun faktor lingkungan. Menurut Hadari Nawawi (1985) lingkungan yang dimaksud adalah lingkungan sekolah yang berkaitan dengan guru, metode mengajar, fasilitas pendidikan yang tersedia, dan lain-lain, lingkungan masyarakat yang berkaitan dengan masyarakat dan pergaulan, serta lingkungan keluarga atau rumah yang berkaitan dengan pola asuh orang tua.

Individu masuk ke sekolah dan kemudian berinteraksi dengan berbagai macam komponen yang membentuk suasana kehidupan di suatu sekolah. Menurut Hadari Nawawi (1985: 116) terdapat 4 komponen yang akan membentuk suasana kehidupan sekolah, yaitu aspek guru, siswa, kurikulum dan fasilitas. Komponen-komponen ini tidak berdiri sendiri tetapi saling mempengaruhi satu sama lain sehingga merupakan bagian yang terintegrasi sebagai sebuah sistem dan saling bekerja sama untuk mencapai tujuan sekolah dalam suatu kondisi baik internal maupun ekternal.

Berdasarkan Hasil interviu pada tanggal 27 September 2010 dengan kepala sekolah, guru bidang kesiswaan di SMP Mika Bakti, maka diperoleh gambaran mengenai sekolah yang menyangkut visi misi sekolah, guru, kurikulum, situasi sekolah dan evaluasi yang ada di SMP Mika Bakti. Sekolah memiliki visi misi yang bertujuan untuk menjadikan siswa yang beriman dan bertakwa kepada Tuhan yang maha esa, dan dengan displin siswa dapat berprestasi, kreatif, inopatif dan berakhlak mulia. Dalam rangka pencapaian visi dan misi tersebut, SMP Mika Bakti telah melaksanakan berbagai usaha, seperti pengadaan sarana dan prasarana yang seadanya yang bisa menunjang proses belajar ngengajar, menciptakan suasana sekolah yang kondusif seperti tenang dalam pelaksanaan belajar, hubungan antara siswa dan guru yang harmonis dan sebagainya. Tetapi kenyataannya, usaha tersebut belum dapat terealisaikan karena sekolah merupakan seperangkat organisasi yang terdiri dari pendidik, peserta didik dan berbagai hal yang ada di dalamnya. Maka dari itu, untuk mencapai visi dan misi sekolah, semua perangkat sekolah harus bekerja sama demi tercapainya visi dan misi sekolah. Selain itu alasan yang muncul adalah persoalan dana yang sangat kurang untuk pengadaan sarana dan prasarana. Jika ada sis- 
wa yang berbakat masih sulit untuk menyalurkan bakatnya baik itu dalam akademik maupun non akademik yang dimiliki siswa tersebut karena kurangnya sarana dan prasarana yang ada.

Jika dilihat dari aspek guru, mereka sudah menjalankan tugasnya dengan baik sesuai dengan bidangnya masing-masing. Para guru berusaha untuk terbuka, terhadap siswa agar terciptanya proses belajar mengajar yang baik, melatih siswa untuk bersikap terbuka, tidak menutupi kesalahan, terus terang, mau dkritik untuk perbaikan masa mendatang, yang terpenting menumbuhkan semangat belajar untuk berprestasi. Namun untuk menumbuhkan semangat siswa untuk berprestasi tidaklah mudah, dikarenakan kurangnya motivasi dalam diri siswa itu sendiri, teman sebaya yang kurang mendukung dan kurangnya perhatian dari orang tua.

Ketika berada di dalam lingkungan sekolah, siswa akan melakukan pemaknaan terhadap objek atau peristiwa yang dilihat dan dirasakan di sekolah. Pemaknaan atau persepsi tentang suasana kehidupan di sekolah merupakan pemaknaan siswa mengenai suasana kehidupan sekolah yang terjadi di suatu sekolah yang akan mempengaruhi perilaku siswa di sekolah itu. Akan tetapi dalam mempersepsikan sesuatu siswa selalu berbeda. Perbedaan dapat dilihat dari prestasi dan tingkah laku yang ditampilkan oleh siswa. Siswa yang mempersepsikan suasana kehidupan sekolah sesuai dengan kebutuhannya biasanya akan senang dan aktif melakukan kegiatan ekstrakulikuler, rajin mengerjakan tugas sekolah, menuruti peraturan yang berlaku di sekolah dan lainnya, sehingga lebih mendorong untuk mau mengikuti proses belajar mengajar di sekolah dengan baik.

Kenyataannya dari hasil wawancara dengan para siswa, diperoleh informasi bahwa siswa sering mengeluh mengenai cara mengajar guru. Yaitu cara mengajar guru yang monoton seperti guru meminta siswa untuk menulis, guru memberikan tugas tetapi jarang diperiksa, hal tersebut membuat siswa merasa malas untuk mengerjakannya, siswa merasa bosan karena siswa hanya mendapat materi pelajaran saja tidak langsung melihat apa yang diterangkan serta jarang ada praktikum. Akibatnya siswa kemudian membanding-bandingkan dengan sekolah lain. Siswa lain mengatakan, bahwa belajar tidak belajar yang memperoleh peringkat satu tetap orang yang sama. Hal ini mengindikasikan bahwa siswa memprsepsi lingkungan sekolah memberikan pengalaman yang kurang menyenangkan dan kurang memenuhi kebutuhannya sebagai siswa, sehingga siswa kurang memiliki dorongan untuk mau belajar dengan rajin di sekolah.

Manusia sebagai makhluk hidup tidak terlepas dari setiap aktivitas tingkah laku yang akan dihadapkan pada proses persepsi. Dalam mengadakan hubungan dengan lingkungan sosialnya individu akan menyadari keberadaan, kemudian menangkap dan mengartikan lingkungan tersebut. Secara keseluruhan proses inilah yang dikenal dengan nama persepsi yang senantiasa berpengaruh terhadap individu dalam kehidupan sehari-hari.

Persepsi merupakan suatu proses dimana kita dapat mengorganisasikan dan menafsirkan pola stimulus dan lingkungan. Pengertian persepsi telah dikemukakan oleh beberapa ahli, antara lain:

Menurut Hilgard \& Atkinson (1983) persepsi adalah proses yang terjadi pada saat individu mengorganisasikan dan menginterpretasikan pada stimulus dalam lingkungan. Menurut Clifford T. Morgan (1987) persepsi adalah suatu proses membedakan stimulus satu dengan stimulus lainnya dan menginterpretasikan makna dari stimulus tersebut. Menurut Linda L. Davidoff (1987) persepsi adalah proses pengorganisasian dan menginterpretasikan data sensorik yang diterima untuk mengembangkan kesadaran akan diri dan lingkungan.

Milton (1981) mengungkapkan persepsi adalah proses menyeleksi, mengorganisasikan, dan menginterpretasikan rangsangan dari lingkungan. Milton (1981) mengemukakan, dengan mengamati sesuatu obyek yang sama, dapat dipersepsi berbreda oleh dua orang atau lebih. Hal ini terjadi karena adanya perbedaan yang disebabkan oleh faktor-faktor sebagai berikut:

The person perceived (yang dipersepsi oleh seseorang). Setiap individu berusaha untuk menilai tingkah laku orang lain, namun seringkali individu tidak menyadari akan adanya variabel yang dapat mempengaruhi hasil penilaian. Proses persepsi dapat dipengaruhi status dari orang yang diamati.

The situation (situasi). Aspek-aspek dari situasi seperti pekerjaan dan atribut-atribut lain yang melekat pada diri seseorang yang melakukan persepsi akan mempengaruhi pengamatannya terhadap obyek situasi atau manusia lainnya. Oleh karena itu masing-masing individu 
mempunyai persepsi yang berbeda dalam mengamati lingkungannya.

Receiver (pengamat). Persepsi dipengaruhi oleh kondisi individual dari pengamat. Salah satu aspek internal yang mempengaruhi persepsi adalah kebutuhan. Seseorang cenderung mengarahkan perhatiannya pada hal-hal yang dapat memenuhi kebutuhannya.

Self perception (persepsi diri). Untuk memahami perilaku orang lain, seseorang harus mengetahui bagaimana ia mengamati dirinya sendiri (self concept). Konsep diri ini dinyatakan sebagai gambaran mental mengenai apa pendapat kita tentang diri kita sendiri. Konsep diri bersifat unik dan bersifat menetap dalam diri individu, sehingga individu tersebut mempunyai gaya hidup tersendiri yaitu bereaksi, berpikir dan bertindak dengan cara tertentu.

Self perception and receiver other (persepsi diri dan pengamatan terhadap orang lain). Dengan mengenal dan memahami diri sendiri akan memudahkan seseorang untuk memahami orang lain secara tepat dan lebih sedikit membuat kesalahan dalam menilai orang lain. Bila seseorang mau menilai dirinya sendiri maka ia cenderung dapat melihat aspek-aspek positif dari orang lain, yang berarti akan memperluas pandangannya dalam melihat dan menilai orang lain.

Personal characteristic (karakteristik pribadi). Karakteristik pribadi mempengaruhi proses seseorang dalam melihat karakteristik orang lain. Dalam menggambarkan orang lain, kita cenderung menggunakan kategori-kategori yang digunakan dalam menggambarkan diri sendiri.

Menurut Sunaryo Kartadinata (1983) suasana kehidupan sekolah merupakan kondisi atau situasi kehidupan sekolah yang dirasakan dan di dalamnya terdapat interaksi antara aspek-aspek yang ada dalam sekolah yang saling berpengaruh satu sama lain, seperti guru, siswa dan norma-norma yang mempengaruhi perilaku individu yang terlibat di sekolah.

Menurut Squires, Huitt dan Hegars (1984: 66) terdapat tiga kondisi yang memiliki peranan penting dalam membentuk suasana kehidupan sekolah yang baik, yaitu: penekanan pada akademik (emphasis on academics), lingkungan yang teratur (an orderly enviroment), harapan untuk sukses (expectation for success). Penjelasan dari ketiga kondisi tersebut adalah sebagai berikut:
Penekanan pada akademik (emphasis on academics). Suasana kehidupan sekolah yang baik akan terbentuk bila kagiatan sekolah lebih ditekankan pada kegiatan bidang akademik. Indikasi dari sekolah yang lebih menekankan kegiatannya pada kegiatan akademik adalah siswa merasakan dapat menguasai materi atau bahan pelajaran, guru memberikan penjelasan yang dapat dimengerti dan guru menggunakan waktu secara efisien dalam mengajarkan keterampilan akademik, guru memberikan tugas pada murid sebagai latihan dimana pemberian tugas ini tidak berlebihan sehingga siswa dapat lebih memahami dan mendalami tugas yang diberikan guru. Selanjutnya guru memberikan hadiah dan pujian secara adil untuk tugas yang dikerjakan dengan baik dan guru memberikan penghargaan atau nilai sesuai dengan prestasi siswa, serta guru memberikan dukungan pada kegiatan belajar siswa. Kondisi sekolah yang lebih menekankan kegiatannya pada kegiatan akademik akan meningkatkan keterlibatan siswa dalam belajar yang kemudian akan meningkatkan prestasi belajar siswa.

Lingkungan yang teratur (an orderly enviroment). Suasana kehidupan sekolah yang baik dapat terbentuk bila terdapat lingkungan sekolah yang teratur. Indikasi dari sekolah yang memiliki lingkungan sekolah yang teratur adalah siswa merasakan prosedur disiplin dilaksanakan secara adil dan sama untuk semua orang. Kegiatan rutin di kelas akan mendukung terjadinya lingkungan yang teratur dimana guru menggunakan waktu belajar dengan tepat serta guru memulai dan menyelesaikan pelajaran dengan tepat waktu. Selain itu, guru memberikan dan menilai pekerjaan rumah, memberikan tugas atau hadiah untuk prestasi yang dicapai, dan dalam menangani masalah disiplin kelas, guru memberikan hukuman dengan tegas dan adil serta menghindari penggunaan kekerasan. Kegiatan rutin di kelas ini akan mengurangi masalah disiplin di kelas, sehingga guru cenderung bersedia dan mempunyai waktu untuk membicarakan masalah pribadi atau belajar yang dimiliki siswa, sehingga akan membantu siswa untuk lebih terlibat dalam kegiatan belajar dan dalam mengerjakan tugas. Sekolah yang mempunyai lingkungan teratur juga memberikan kesempatan pada siswa untuk ikut berpartisipasi dalam sekolah yaitu siswa menjaga fasilitas yang ada di sekolah. Sekolah memberikan kesempatan pada siswa untuk terlibat dalam aktivitas 
kelas, perkumpulan yang ada di sekolah dan kegiatan yang diadakan di sekolah, serta penggunaan dan pemanfaatan perpustakaan sekolah. Hal ini mengindikasikan bahwa siswa menghargai keberadaan perpustakaan yang kemudian akan mendukung kegiatan akademik siswa. Siswa yang berpartisipasi dalam kegiatan sekolah tidak akan menimbulkan masalah disiplin karena siswa merasa ikut memiliki sekolah dan merasa menjadi bagian dari sekolah.

Harapan untuk Sukses (expectations for success). Sekolah yang baik dapat terbentuk bila adanya harapan untuk sukses yang diekspresikan oleh guru, yaitu siswa diharapkan dapat mencapi keberhasilan dengan standar yang tinggi, tetapi masuk akal. Siswa diharapkan dapat mencapai kemajuan dalam belajar yang ditandai dengan pencapaian prestasi. Siswa yang mempunyai keyakinan bahwa dengan usaha dan kerja keras ia dapat meraih prestasi dalam belajar yang baik. Harapan untuk sukses diekspresikan dengan suatu cara sehingga siswa mengetahui apa yang diharapkan darinya dan mempercayai bahwa mereka dapat mencapai apa yang diharapkan tersebut. Harapan untuk sukses diekspresikan juga oleh guru dengan memperhatikan prestasi belajar siswa serta dengan memberikan reward atau hadiah untuk tugas yang dikerjakan dengan baik dan memberikan kesempatan pada siswa untuk berpartisipasi dalam kegiatan sekolah, misalanya dalam kegiatan OSIS. Harapan untuk sukses ini akan mendorong sekolah agar lebih menekankan kegiatannya di bidang akademik dan agar sekolah dapat mempunyai lingkungan yang teratur.

Menurut Squires et al (1984: 72) siswa yang berada dalam iklim sekolah yang baik akan merasakan bahwa sekolah membantu mereka untuk dapat menguasai pelajaran dan membantu kegiatan belajar. Hal ini berarti bahwa siswa mempersepsikan iklim atau suasana kehidupan sekolah yang ada di sekitarnya. Jika siswa akan memiliki persepsi yang positif terhadap suasana kehidupan sekolahnya apabila siswa merasakan sekolah membantu mereka dalam menjalani proses belajar mengajar disekolahnya, sehingga semangat siswa untuk berprestasi di bidang pelajaran semakin tinggi.

Seseorang berbuat, bertindak atau bertingkah laku dilatarbelakangi oleh kekuatan dorongan dalam dirinya yang disebut motif (Gunarsa, 1976: 92). Begitu pula untuk berprestasi diperlukan dorongan dari dalam diri atau adanya motif berprestasi pada individu. Siswa yang memiliki dorongan untuk berprestasi atau motif berprestasi yang tinggi cenderung akan belajar keras dan berjuang untuk mengatasi permasalahan yang berkaitan dengan proses belajarnya, sehingga mencapai prestasi baik sesuai dengan kemampuannya. Hal ini sesuai dengan pendapat Raynor (1970) bahwa individu dengan motif berprestasi tinggi cenderung mendapatkan angka-angka yang baik dalam pelajaran yang berkaitan dengan karir masa depan mereka (Rosdiyanti, 1997: 33).

Motif berasal dari bahasa latin 'movere' yang berarti 'to move' atau menggerakkan. Motif pada umumnya dianggap sebagai suatu potensi atau suatu kekuatan yang ada dalam diri seseorang, sedangkan motivasi adalah perwujudan dari potensi motif itu sendiri, yang biasanya dimanifestasikan dalam bentuk tingkah laku. Berikut ini pengertian dari motif itu sendiri: Rochman Natawijaya (1978: 86), mengatakan motif sebagai dorongan yang membuat seseorang berminat melakukan sesuatu. Bagi manusia motif merupakan dorongan, keinginan, hasrat yang menjadi penggerak yang berasal dari dalam diri manusia, yang memberikan tujuan dan arah kepada kita. Sunaryo Kartadinata (1976: 31) memgemukakan motif adalah suatu kondisi dalam diri individu yang mempengaruhi kesiapan, mendorong serta mengarahkan kegiatan individu, banyak menentukan tingkat usaha yang mungkin dilakukan dan hasil yang diperoleh di dalam mencapai suatu tujuan.

Berdasarkan pendapat di atas dapat ditarik kesimpulan bahwa motif merupakan suatu dorongan dalam diri individu yang timbul karena adanya suatu kebutuhan tertentu yang mempengaruhi kesiapan individu tersebut dalam mencapai tujuan tertentu dengan hasil tertentu pula.

Motif berprestasi termasuk ke dalam motif yang dipelajari atau motif sekunder. Motif berprestasi bukan merupakan bawaan sejak lahir, melain merupakan hasil interaksi individu dengan lingkungan keluarga, sekolah, maupun lingkungan masyarakat.

Mc Clelland (1976: 39) menyebutkan bahwa motif berprestasi merupakan dorongan yang menggerakkan individu untuk mengatasi tantangan dan hambatan dalam mencapai tujuan. "Achievement motive is a drive to move people to overcome challenges and obstacles in the pursuit of goals". Selain itu, Winkel 
(1991: 90) mendefinisikan motif berprestasi sebagai penggerak dalam diri individu untuk mencapai taraf prestasi setinggi mungkin, demi penghargaan kepada diri sendiri.

Berdasarkan pendapat-pendapat tersebut, dapat dirumuskan bahwa motif berprestasi adalah suatu dorongan dalam diri individu untuk melakukan aktivitas dalam rangka mengusahakan kesuksesan atau memperoleh hasil sebaik-baiknya berdasarkan standar kesernpurnaan dengan segenap potensi dan dukungan yang dimiliki.

Berdasarkan hasil wawancara peneliti dengan guru bidang kesiswaan dan guru-guru lain, diperoleh informasi bahwa dalam proses belajar mengajar di kelas, terdapat banyak siswa kelas IX yang suka membolos, terlambat datang ke sekolah, terlambat masuk ke dalam kelas setelah waktu istirahat selesai, ribut di dalam kelas ketika guru sedang menerangkan, hasil ulangan kurang memuaskan, atau segaja tidak mengikuti pelajaran dengan alasan malas, diam diluar kelas ketika guru tidak masuk. Hal ini dapat menjadi indikasi kurangnya dorongan pada diri siswa untuk belajar dengan sungguhsungguh agar dapat berprestasi dengan baik.

Siswa yang memaknakan suasana lingkungan sekolahnya sesuai dengan kebutuhan berprestasi, maka siswa cenderung akan melakukan aktivitas belajar di sekolah dengan baik karena kebutuhan untuk berprestasi disediakan di sekolah, seperti guru-guru yang membantu dalam belajar, teman-teman yang dapat diajak kerjasama, fasilitas sekolah yang lengkap, sehingga siswa menjadi terdorong untuk rajin belajar dan berprestasinya meningkat. Hal ini menunjukkan siswa memiliki motif berprestasi yang tinggi dalam belajar.

Sebaliknya siswa yang memaknakan suasana kehidupan di sekolahnya kurang sesuai dengan kebutuhan untuk berprestasi cenderung akan menghindari aktivitas belajar di sekolahnya karena merasa lingkungan sekolah memberikan pengalaman yang tidak menyenangkan bagi dirinya dan kurang membantu untuk dapat mengikuti proses belajar dengan baik seperti guru yang jarang datang, guru yang mengajarnya membosankan, teman-teman yang tidak kompak, fasilitas belajar yang kurang, dan lain-lain. Sehingga mereka cenderung untuk membolos, terlambat datang, ribut, dan lainlain. Situasi ini dapat menjadi indikasi kurangnya dorongan atau motif berprestasi dalam diri siswa, sehingga akan mempengaruhi prestasi siswa.

Berdasarkan fenomena yang telah dipaparkan, peneliti menduga bahwa siswa yang memiliki persepsi positif terhadap suasana kehidupan sekolah menunjukkan indikasi motif berprestasi yang tinggi sedangkan siswa yang memiliki persepsi negatif terhadap suasana kehidupan sekolah menunjukkan indikasi motif berprestasi yang rendah.

\section{METODE PENELITIAN}

Pendekatan yang digunakan dalam penelitian ini adalah pendekatan kuantitatif, dengan menggunakan metode korelasional sebab akibat, yaitu sebuah penelitian yang bertujuan untuk menemukan ada tidaknya hubungan sebab akibat dari dua variabel dan untuk melihat derajat keeratan hubungan kedua variabel tersebut. Penelitian ini melibatkan dua variabel yang akan dilihat pengaruhnya. Variabel pertama adalah persepsi tentang suasana kehidupan sekolah, yaitu pemaknaan siswa mengenai iklim atau suasana kehidupan sekolahnya yang akan berpengaruh kepada perilaku siswa tersebut (Winkel, 1991).

Variabel kedua adalah motif berprestasi, yaitu suatu dorongan dalam diri siswa untuk melakukan aktivitas dalam rangka mengusahakan dan memperjuangkan kesuksesan atau memperoleh hasil yang sebaik-baiknya berdasarkan standar kesempurnaan dengan segenap potensi dan dukungan yang dimiliki. Mc. Clelland (dalam Sunaryo, 1983: 42).

Populasi dalam penelitian ini adalah siswa siswa kelas IX SMP Mika Bakti yang berjumlah 38 orang. Untuk mengetahui adanya pengaruh dalam penelitian ini, maka peneliti akan menggunakan program SPSS versi 17. Sedangkan statistik uji yang akan digunakan adalah analisis regresi sederhana.

\section{HASIL DAN PEMBAHASAN}

\section{Hasil}

Berdasrkan hasil analisis diketahui bahwa nilai $\mathrm{F}$ hitung sebesar 0.139 dengan tingkat signifikansi 0.712 (tidak signifikan). Oleh karena probabilitas (0.712) lebih besar dari alpha $(0,05)$, maka dapat dikatakan bahwa persepsi siswa tentang suasana kehidupan sekolah se- 
cara umum tidak berpengaruh terhadap motif berprestasi, sehingga hipotesis ditolak.

Berdasarkan hasil analisis deskriptif diketahui bahwa dari $47.1 \%$ (16 orang) subjek yang memiliki persepsi negatif, $20.6 \%$ (7 orang) subjek menunjukkan tingkat motif berprestasi yang rendah, sedangkan $26.5 \%$ (9 orang) subjek subjek lainnya menunjukkan tingkat motif berprestasi yang tinggi. Selanjutnya, dari 52.9\% (18 orang) subjek yang memiliki persepsi positif, $29.4 \%$ (10 orang) subjek menunjukkan tingkat motif berprestasi yang rendah, sedangkan $23.5 \%$ (8 orang) subjek subjek lainnya menunjukkan tingkat motif berprestasi yang tinggi.

\section{Pembahasan}

Berdasarkan hasil perhitungan diketahui bahwa hipotesis yang diajukan dalam penelitian ini ditolak, artinya tidak terdapat pengaruh persepsi siswa tentang suasana sekolah terhadap motif berprestasi. Hal tersebut menurut peneliti menunjukkan beberapa hal, yaitu:

Pertama, dari hasil analisis deskriptif diketahui bahwa dari 47.1\% (16 orang) subjek yang memiliki persepsi negatif, 20.6\% (7 orang) subjek menunjukkan tingkat motif berprestasi yang rendah, sedangkan $26.5 \%$ (9 orang) subjek subjek lainnya menunjukkan tingkat motif berprestasi yang tinggi.

Sebagian siswa yang memaknakan suasana kehidupan di sekolahnya kurang sesuai dengan kebutuhan untuk berprestasi cenderung akan menghindari aktivitas belajar di sekolahnya karena merasa lingkungan sekolah memberikan pengalaman yang tidak menyenangkan bagi dirinya dan kurang membantu untuk dapat mengikuti proses belajar dengan baik seperti guru yang jarang datang, guru yang cara mengajarnya membosankan, teman-teman yang tidak kompak, fasilitas belajar yang kurang, dan lain-lain. Sehingga mereka cenderung untuk bolos, terlambat datang, ribut, dan lain-lain.

Berdasarkan data penelitian tersebut terdapat hal yang menarik yaitu jumlah siswa yang memiliki persepsi negatif dan memiliki motif berprestasi tinggi lebih banyak bila dibanding dengan siswa yang memiliki persepsi negatif dan memiliki motif berprestasi rendah.

Hal tersebut dapat saja terjadi karena ketika siswa mempersepsi suasana kehidupan sekolah dengan negatif, maka ia akan berusaha untuk mengandalkan sumber di luar sekolah, agar bisa tetap berprestasi dan mampu bersaing dengan siswa dari sekolah yang lain. Sesuai dengan Mc Clelland (Haditono, 1989: 63) bahwa terdapat dua faktor utama yang paling mempengaruhi motif berprestasi dari, yaitu faktor individual dan faktor lingkungan.

Faktor individual yang dimaksud dalam hal ini terdiri dari faktor intelegensi dan faktor penilaian individu terhadap kemampuan diri sendiri. Intelegensi merupakan kecakapan yang bersifat potensial yang dimiliki seseorang dan merupakan salah satu unsur penting dalam proses pemecahan masalah yang dilakukan individu. Faktor lain itu adalah penilaian individu terhadap kemampuan dirinya. Faktor ini merupakan salah satu komponen pribadi yang dibentuk berdasarkan penilaian atau pandangan orang lain tentang diri individu maupun melalui penilaian individu sendiri tentang kondisi fisik, kemampuan melakukan suatu tugas atau apa yang diusahakannya.

Penilaian ini dapat berupa penilaian positif atau negatif. Bila individu memiliki penilaian diri yang positif, maka ia akan percaya pada kemampuan diri sendiri, aktif berusaha dan berani menghadapi tantangan. Dalam hal berprestasi, individu akan merasa tertantang untuk menyelesaikan masalah atau tugas yang menuntut keahlian atau kemampuan, atau berusaha kuat mencapai standar keunggulan yang ditetapkannya. Sebaliknya, seseorang yang memiliki penilaian diri negatif, maka ia akan menapilkan kurang percaya diri dan kurang berani menghadapi tantangan, meskipun ia sebenarnya memiliki kemampuan.

Yang dimaksud dengan faktor lingkungan di sini adalah segala sesuatu yang berada di luar diri individu yang mempengaruhi motif berprestasi. Selain lingkungan sekolah lingkungan sosial dan lingkungan keluarga juga dianggap berpengaruh terhadap meningkatnya motif berprestasi.

Lingkungan sekitar yang banyak memberikan rangsangan intelektual akan banyak membantu meningkatkan motif berprestasinya. Di samping itu lingkungan sekitar rumah yang memberikan kesempatan kepada individu untuk lebih dapat mengekspresikan kemampuannya akan membuat siswa lebih percaya diri, sehingga meskipun mengalami kegagalan ia akan terdorong untuk mengatasi dan berusaha lebih baik.

Apabila relasi di lingkunan keluarga berlangsung harmonis dan memberikan rasa aman, maka individu merasa bebas untuk mengeksplorasi dan mengekspresikan diri. Sese- 
orang yang diberi kesempatan untuk mengekspresikan diri dan berhasil, akan merasa tertantang untuk meraih prestasi yang lebih baik. Bila mengalami kegagalan, ia tidak akan menyalahkan lingkungan karena ia menyadari bahwa kegagalan tersebut disebabkan karena kurangnya usaha dalam meraih prestasi yang diinginkan.

Kedua, dari hasil analisis deskriptif diketahui bahwa Dari 52.9\% (18 orang) subjek yang memiliki persepsi positif, $29.4 \%$ (10 orang) subjek menunjukkan tingkat motif berprestasi yang rendah, sedangkan $23.5 \%$ (8 orang) subjek subjek lainnya menunjukkan tingkat motif berprestasi yang tinggi.

Siswa memaknakan suasana lingkungan sekolahnya sesuai dengan kebutuhan berprestasi, maka siswa cenderung akan melakukan aktivitas belajar di sekolah dengan baik karena kebutuhan untuk berprestasi disediakan di sekolah, seperti guru-guru yang membantu dalam belajar, teman-teman yang dapat diajak kerjasama, fasilitas sekolah yang lengkap, sehingga siswa menjadi terdorong untuk rajin belajar dan diharapkan prestasinya meningkat.

Mc Clelland mengungkapkan bahwa motif berprestasi merupakan kebutuhan pada setiap individu untuk mencapai atau bahkan melampaui ukuran keberhasilan yang ditetapkannya sendiri maupun dari orang lain. Individu dengan motif berprestasi cenderung ingin bekerja lebih baik dari orang lain, senang melakukan pekerjaan sendiri dan tidak menggantungkan diri kepada orang lain. Berdasarkan data penelitian tersebut, terdapat hal yang menarik yaitu jumlah siswa yang memiliki persepsi positif dan memiliki motif berprestasi rendah lebih banyak bila dibanding dengan siswa yang memiliki persepsi positif dan memiliki motif berprestasi tinggi.

Hal tersebut dapat saja terjadi karena ketika siswa mempersepsi suasana kehidupan sekolah dengan positif, maka ia akan menganggap bahwa apa yang berada di sekolah itu sudah mencukupi kebutuhan belajarnya. Sesuai dengan Krech, Cruchfield \& Ballachey (1983) bahwa salah satu faktor yang mempengaruhi persepsi seperti kebudayaan dan status sosialekonomi. Perbedaan status sosial-ekonomi berarti perbedaan lingkungan yang mempengaruhi perkembangan seseorang. Perbedaan ini dapat terletak pada pandangan-pandangan yang diterimanya dari keluarga dan lingkungan, juga norma dan kebiasaan yang ada. Sebagian besar subjek dalam penelitian ini berasal dari kelompok sosial-ekonomi menengah ke bawah, jadi meskipun mereka memiliki persepsi yang positif terhadap suasana kehidupan sekolah, hal tersebut tidak membuat motif berprestasi mereka meningkat. Mereka beranggapan bahwa prestasi yang tinggi di sekolah tidak berpengaruh banyak terhadap masa depannya. Artinya meskipun mereka berprestasi di sekolah, tetapi orang tua mereka tidak akan sanggup membiayai pendidikan selanjutnya.

Hasil lain yang diperoleh dalam penelitian ini adalah adanya aspek yang berpengaruh terhadap motif berprestasi, yaitu persepsi siswa tentang aspek kurikulum. Hasil penelitian tersebut sesuai dengan apa yang dikatakan oleh Nawawi (1985: 116), yaitu bahwa kurikulum yang digunakan di sekolah sangat besar pengaruhnya terhadap aktifitas kelas dalam mewujudkan proses belajar mengajar yang berdaya guna bagi pembentukan pribadi siswa.

Hal tersebut dapat dipahami, karena berdasarkan hasil wawancara terhadap sebagian besar besar siswa yang memiliki motif berprestasi tinggi, sebagian besar dari mereka menganggap bahwa jumlah mata pelajaran yang disajikan oleh sekolah sudah disesuaikan dengan kemampuan siswa. Sebagian yang lain menganggap bahwa metode diskusi yang diterapkan di sekolah mampu melatih daya pikir. Ada juga siswa yang menganggap bahwa metode mengajar yang diterapkan oleh guru di sekolah mudah dipahami. Siswa lainnya menganggap bahwa kegiatan ekstrakurikuler yang ada bermanfaat bagi siswa.

\section{SIMPULAN DAN SARAN}

\section{Simpulan}

Berdasarkan hasil analisis dan pembahasan tentang pengaruh persepsi siswa tentang suasana kehidupan sekolah terhadap motif berprestasi dapat ditarik simpulan bahwa tidak terdapat pengaruh persepsi siswa tentang suasana kehidupan sekolah terhadap motif berprestasi siswa kelas IX SMP Mika Bakti.

\section{Saran}

Berdasarkan hasil penelitian yang telah dilakukan, dengan memperhatikan keterbatasan-keterbatasan dalam penelitian ini, peneliti 
mengajukan saran-saran agar dapat dijadikan bahan pertimbangan sebagai berikut:

Pertama, bagi pihak sekolah, disarankan agar memberikan pelatihan berhubungan dengan motif berprestasi sehingga diharapkan para siswa memperoleh prestasi yang lebih baik.

Kedua, dalam penelitian ini peneliti hanya mengambil sampel siswa dari satu sekolah. Untuk mendapatkan gambaran yang lebih komprehensif peneliti menyarankan untuk mengadakan penelitian dengan populasi yang lebih luas atau mencoba mengambil populasi dari tingkat pendidikan yang berbeda, seperti SMP, SMA atau Perguruan Tinggi.

Ketiga, untuk penelitian selanjutnya, dikarenakan pada penelitian ini masih terdapat kasus yang menarik dan perlu dijawab serta diteliti kembali, yaitu jumlah siswa yang memiliki persepsi negatif dan memiliki motif berprestasi tinggi lebih banyak bila dibanding dengan siswa yang memiliki persepsi negatif dan memiliki motif berprestasi rendah, serta jumlah siswa yang memiliki persepsi positif dan memiliki motif berprestasi rendah lebih banyak bila dibanding dengan siswa yang memiliki persepsi positif dan memiliki motif berprestasi tinggi. Karenanya peneliti memberi masukkan kepada peneliti lain untuk mencari variabel lain yang diduga memiliki pengaruh yang lebih signifikan terhadap motif berprestasi.

\section{DAFTAR PUSTAKA}

Arikunto, S. 2006. Prosedur Penelitian. Jakarta: Rineka Cipta

Azwar, Saefudin. 2002. Penyusunan Skala Psikologi. Yogyakarta: Pustaka Pelajar

Friedenberg, Lisa.1995. Psychological Testing: Design Analysis and Use. Allyn and Bacon. London

Gunarsa, Singgih G. 1976. Psikologi untuk Remaja. Jakarta: BPK Gunung Mulia

Hadi,S. 2004. Metodelogi Research. Yogyakarta: Andi Offset

Haditono, Siti Rahayu. 1989. Psikologi Perkembangan. Yogyakarta: Gajah Mada University Press

Hilgard, Ernest R., Atkinson, Rita L., Atkinson, Richard C. 1995. Pengantar Psikologi. Jakarta: Erlangga

Hurlock, E.B. 1973. Adoselent Development. Tokyo: Mc. Graw Hill Koga Kusha, Ltd.
Hurlock, E.B. 1994. Psikologi Perkembangan Suatu Pendekatan Sepanjang Rentang Kehidupan. Jakarta: Erlangga

Ilham, Pradono. 2001. Hubungan antara Persepsi Terhadap Pola Asuh Authoritative Orang Tua Pengganti dengan Kecerdasan Emosional Remaja Usia 17-18 Tahun Pada Panti Asuhan Muhamadiyyah Bandung. Skripsi. Fakultas Psikologi, UNISBA

Kartadinata, Sunaryo. 1983. Kontribusi Iklim Kehidupan Keluarga dan Iklim Kehidupan Sekolah terhadap Adekuasi Penyesuaian Diri. Tesis: FPS IKIP Bandung

Mc Clelland, Atkinson. 1976. Achievement Motivation. Appleton-Century, Craft lnc, New York

Milton, Charles R. 1981. Human Behavior in Organization: Three Levels of Behavior. New Jersey: Prentice-Hail,Inc

Monks, F.J, K \& Haditono, S.R. 1999. Psikologi Perkembangan. Yogyakarta: Gajah Mada University Press.

Nawawi, Hadari. 1981. Organisasi Kelas dan Pengelolaan Kelas. Jakarta: Gunung Agung

Nurlaela, L. 2004. Hubungan antara Persepsi terhadap Pesantren dengan Penyesuaian Santri di Sekolah pada Santri Mu'alimin Pesantren Persatauan Islam No. 96 Banyu Garut. Skripsi. UIN Bandung

Rosdiyanti, Irma. 1997. Hubungan Self Esteem dan Motif Berprestasi dengan Prestasi Belajar pada Siswa SMU I \& II Kabupaten Cirebon. Skripsi. UNISBA

Slameto. 1995. Belajar dan Faktor-Faktor yang Mempengaruhinya. Jakarta: Rineka Cipta

Squires, David A. Huitt \& William. G. \& Segars, John K. 1984. Effective Schools \& Classroom: A Research-Based Perspective. Virginia: Assistant For Supervision \& Curriculum Development

Sudjana. 2002. Metoda Statistika edisi Ke-6. Bandung: Tarsito

Syaodih, Nana S. 1983. Kontribusi Konsep Mengajar dan Motif Berprestasi Terhadap Proses Belajar dan Hasil Belajar. Disertasi. FIP. IKIP Bandung

Syah, Muhibbin. 1995. Psikologi Pendidikan, Suatu Pendekatan Baru. Cetakan ke-3. Bandung: Remaja Rosdakarya Offset.

Syamsuddin, Abin. 1985. Psikologi Pendidikan. IKIP Bandung 
Udai, Pareek. 1996. Perilaku Organisasi: Pedoman ke arah Pemahaman Proses Komunikasi antar Pribadi dan Motivasi Kerja. Cetakan ketiga. Jakarta: PT. Pustaka Binaan Pressindo

Walgito, B. 2002. Pengantar Psikologi Umum. Yogyakarta: Andi Offset
Winkel, W.S. 1996. Psikologi Pengajaran. Jakarta: PT. Grasindo

www.accel-team.com

www.UU-Sisdiknas-2003.com

Yusuf, Syamsu. 2000. Psikologi Perkembangan Anak dan Remaja. Bandung: PT Remaja Rosda Karya 